\title{
Effect of Direct-Fed Microbials on Performance, Diet Digestibility, and Rumen Characteristics of Holstein Dairy Cows ${ }^{1}$
}

\author{
M. L. Raeth-Knight, ${ }^{\star 2}$ J. G. Linn, ${ }^{*}$ and H. G. Jung ${ }^{\star} \dagger$ \\ *Department of Animal Science, University of Minnesota, St. Paul 55108 \\ †USDA-ARS, St. Paul, MN 55108
}

\begin{abstract}
The objective of this study was to determine the effect of feeding direct-fed microbial (DFM) products containing Lactobacillus acidophilus and Propionibacteria freudenreichii on the performance, nutrient digestibility, and rumen fermentation of Holstein dairy cows in midlactation. Experiments were conducted from February to May 2003. Cows were fed 1 of 3 dietary treatments: 1) $1 \times 10^{9}$ colony-forming units (cfu)/d of live L. acidophilus strain LA747 and $2 \times 10^{9}$ cfu/d of live $P$. freudenreichii strain PF24 (DFM1); 2) $1 \times 10^{9} \mathrm{cfu} / \mathrm{d}$ of live L. acidophilus strain LA747, $2 \times$ $10^{9} \mathrm{cfu} / \mathrm{d}$ of live $P$. freudenreichii strain PF24, and 5 $\times 10^{8} \mathrm{cfu} / \mathrm{d}$ of L. acidophilus strain LA45 (DFM2); or 3 ) lactose (control). Treatments were administered by mixing $45 \mathrm{~g}$ of finely ground corn with $5 \mathrm{~g}$ of DFM products or lactose and top dressing on the total mixed rations once daily. All cows received the same total mixed ration: $12.7 \%$ alfalfa hay, $46.2 \%$ corn silage, and $41.1 \%$ concentrate on a dry matter (DM) basis. In study 1 (lactation study), 39 multiparous and 18 primiparous Holstein cows were blocked by parity and randomly assigned to treatments for $84 \mathrm{~d}$. Starting on d 35, fecal grab samples were collected from each cow at 5- to 8$\mathrm{h}$ intervals over $48 \mathrm{~h}$ for digestibility measurements. A rumen fermentation study (study 2) was conducted concurrently with the lactation study. Three rumenfistulated, multiparous Holstein cows were randomly assigned to dietary treatments DFM1, DFM2, and control in a $3 \times 3$ Latin square design with 28 -d periods. In study 1 , there was no difference in average DM intake $(23.9,23.6$, and $24.2 \mathrm{~kg} / \mathrm{d})$ or $4 \%$ fat-corrected milk $(36.8,35.3$, and $36.2 \mathrm{~kg} / \mathrm{d})$ for treatments DFM1, DFM2, and control. Percentage or yield of milk compo-
\end{abstract}

\footnotetext{
Received October 4, 2006.

Accepted December 18, 2006.

${ }^{1}$ Mention of a proprietary product does not constitute a recommendation or warranty of the product by the University of Minnesota or the USDA and does not imply approval to the exclusion of other suitable products.

${ }^{2}$ Corresponding author: raeth003@umn.edu
}

nents also did not differ among treatments. Feed efficiency averaged $1.52 \mathrm{~kg}$ of $4 \%$ fat-corrected milk/kg of DM intake and did not differ among treatments. There were no differences in apparent DM, crude protein, neutral detergent fiber, or starch digestibility among treatments. In study 2 , there was no difference in rumen $\mathrm{pH}$ and concentrations of ammonia or total volatile fatty acids measured at $0,1,3$, and $6 \mathrm{~h}$ after feeding. Under the conditions of these studies, supplementing midlactation cows with DFM products containing $L$. acidophilus and $P$. freudenreichii did not affect cow performance, diet digestibility, or rumen fermentation.

Key words: direct-fed microbial, dairy cow, midlactation

\section{INTRODUCTION}

Direct-fed microbials (DFM) are defined as a source of live, naturally occurring microorganisms (Krehbiel et al., 2003). They are utilized in dairy production to improve animal performance, feed efficiency, and health (Yoon and Stern, 1995). Due to rising public concern over the use of antibiotics in animal production, there continues to be interest in the feeding of "natural" feed additives such as DFM, and, according to Nocek and Kautz (2006), the inclusion of a DFM in dairy cow diets has become a generally accepted practice.

A definitive mode of action for bacterial or fungal DFM has not been established, although a variety of mechanisms have been suggested. These include the modification of rumen or lower gut microbial populations, alteration of rumen fermentation patterns, increased intestinal nutrient flow, improved diet digestibility, and immune system modulation (Yoon and Stern, 1995; Krehbiel et al., 2003).

The effect of DFM supplementation on cow performance or rumen fermentation has been reviewed by several authors (Martin and Nisbet, 1992; Jouany, 1994; Newbold, 1995; Yoon and Stern, 1995; Krehbiel et al., 2003). Although DFM supplementation has improved milk production, component yield, feed effi- 
ciency, and health, animal response to DFM have been inconsistent. In addition, results of DFM studies conducted with dairy cattle are difficult to compare because of the many different organisms, strains of organisms, and combinations of multiple organisms that have been supplemented. Other differences among studies include the DFM inclusion level in the diet, diet composition, feed intake, and feeding frequency, along with animal factors such as age, physiological stage, health, and stress status (Wagner et al., 1990).

Fungal DFM products have been studied to a greater extent in lactating dairy cows than have bacterial DFM products, and the effect of bacterial DFM products on cow performance has not been definitively demonstrated. Lactobacillus acidophilus and Propionibacterium freudenreichii are the primary bacterial organisms fed to ruminants. Feeding these organisms together may be advantageous, because $L$. acidophilus is a lactate-producing bacteria and $P$. freudenreichii is a lactate-utilizing bacteria that produces propionate, a glucose precursor, as a product of fermentation. The objective of our study was to determine the effect of feeding a bacterial DFM containing $L$. acidophilus and $P$. freudenreichii on the performance, nutrient digestibility, and rumen fermentation of Holstein dairy cows in midlactation.

\section{MATERIALS AND METHODS}

Two studies, a lactation study that included digestibility measurements and a rumen fermentation study with fistulated cows, were conducted at the University of Minnesota Dairy Research Facility. The studies were conducted from February through May 2003. All cows were housed in a tie-stall barn and cared for according to the University of Minnesota Institutional Animal Care and Usage Committee recommendations (animal subjects code 0212A38841).

\section{Lactation Study}

Cows and Diets. Thirty-nine multiparous and 18 primiparous lactating Holstein cows were blocked by parity and randomly assigned to 1 of 3 dietary treatments: 1) DFM1: $1 \times 10^{9} \mathrm{cfu} / \mathrm{d}$ of live L. acidophilus strain LA747 and $2 \times 10^{9} \mathrm{cfu} / \mathrm{d}$ of live $P$. freudenreichii strain PF24; 2) DFM2: $1 \times 10^{9} \mathrm{cfu} / \mathrm{d}$ of live L. acidophilus strain LA747, $2 \times 10^{9} \mathrm{cfu} / \mathrm{d}$ of live $P$. freudenreichii strain PF24, and $5 \times 10^{8} \mathrm{cfu} / \mathrm{d}$ of LA strain LA45; and 3) Control: Lactose

At the initiation of the study, DIM averaged $74 \pm 32$ (mean $\pm \mathrm{SD}$ ), $69 \pm 32$, and $69 \pm 32 \mathrm{~d}$, and milk production was $42 \pm 7,43 \pm 7$, and $43 \pm 8 \mathrm{~kg} / \mathrm{d}$ for treatments DFM1, DFM2, and control, respectively. Dietary treat-
Table 1. Ingredient composition of diet

\begin{tabular}{lc}
\hline Ingredient & Amount \\
\hline & \% of DM - - \\
Corn silage & 47.9 \\
Protein mix & 35.9 \\
Alfalfa hay & 12.9 \\
Corn grain & 3.3 \\
& \% of protein mix \\
Corn & 28.3 \\
Soybean meal, 46\% & 27.6 \\
SoyPlus ${ }^{1}$ (60\% bypass protein) & 8.40 \\
Whole cottonseed & 12.5 \\
Distillers dried grains & 8.4 \\
Sodium bicarbonate & 2.1 \\
Ca & 1.6 \\
Choice white grease & 2.1 \\
Megalac ${ }^{2}$ (bypass fat) & 2.5 \\
Bloodmeal & 2.9 \\
Mixing salt & 1.1 \\
Dicalcium phosphate & 0.6 \\
Urea, 278\% & 0.6 \\
Vitamin-trace mineral premix & 0.5 \\
Dynamate ${ }^{3}$ (S, K, and Mg) & 0.4 \\
Magnesium oxide & 0.4 \\
\hline
\end{tabular}

\footnotetext{
${ }^{1}$ Manufactured by West Central (Ralston, IA).

${ }^{2}$ Manufactured by a division of Church \& Dwight Co., Inc. (Princeton, NJ).

${ }^{3}$ Manufactured by a division of IMC-Agrico Co. (Mundelein, IL).
}

ments were fed for $84 \mathrm{~d}$. Treatments were prepared by mixing $45 \mathrm{~g}$ of finely ground corn with $5 \mathrm{~g}$ of live microbial product (Nutrition Physiology Corp., Indianapolis, IN) or lactose. The treatments were stored in individual, daily-sized packages at $-30^{\circ} \mathrm{C}$ until fed. All cows received the same TMR (Table 1), which was formulated to meet or exceed nutrient recommendations for $40 \mathrm{~kg} / \mathrm{d}$ of milk production (NRC, 2001). The TMR was offered twice daily at 0600 and $1400 \mathrm{~h}$, allowing for approximately $5 \%$ feed refusal. Treatment mixtures were top-dressed on the $1400 \mathrm{~h}$ feeding of the TMR. Dry matter of the corn silage was determined weekly, and dietary amounts were adjusted if silage DM varied more than 2 percentage units. Cows were milked twice daily at 0500 and 1600 h. Feed intake and milk production were recorded daily throughout the study.

Four cows were removed from the study for reasons not attributed to treatments. Two cows were removed from treatment DFM1; 1 cow because of severe mastitis and 1 cow died. One cow each was removed from the DFM2 and the control treatments because of severe mastitis and death, respectively.

Sample Collection and Analysis. Individual milk samples were taken once weekly during the 1400 and $0500 \mathrm{~h}$ milking of consecutive days. Samples were analyzed for fat, protein, lactose, MUN, and SCC (Minnesota DHIA, Sauk Center). The Gaines formula (NRC, 
2001) was used to calculate $4 \% \mathrm{FCM}(\mathrm{kg} / \mathrm{d}=0.4 \times$ milk, $\mathrm{kg} / \mathrm{d}+15 \times$ fat, $\mathrm{kg} / \mathrm{d})$. Energy-corrected milk was calculated as $[\mathrm{ECM}, \mathrm{kg} / \mathrm{d}=$ milk yield $\times(0.0929 \times \mathrm{fat}$ $\%)+(0.0563 \times$ true protein $\%)+(0.0395 \times$ lactose $\%)]$ $\div 0.749$ (Krause and Combs, 2003).

Diet ingredient samples were taken weekly. A sample of feed refusal was taken daily and then composited by week for analysis. Feed and feed refusal samples were dried for $24 \mathrm{~h}$ in a $60^{\circ} \mathrm{C}$ forced-air oven to determine DM content and ground to pass through a 1-mm screen (Wiley mill, Thomas Scientific, Swedesboro, NJ). Organic matter was determined by ashing the samples in a muffle furnace at $500^{\circ} \mathrm{C}$ (AOAC, 1995). Samples were analyzed for CP (NA2100 protein nitrogen analyzer, ThermoQuest Italia SPA., Milan, Italy; AOAC, 1995), and ether extract (AOAC, 1995). The Ankom $^{200}$ fiber system (Ankom Technology Corp., Fairport, NY) was used for sequential analysis of NDF, $\mathrm{ADF}$, and acid detergent lignin (Hintz et al., 1996). Samples were analyzed for NDF using sodium sulfite and $\alpha$-amylase (A3306, Sigma Chemical Co., St. Louis, $\mathrm{MO})$. Acid detergent lignin was determined by digesting the ADF residue in $72 \%$ sulfuric acid (Van Soest et al., 1991). Neutral detergent insoluble CP and acid detergent insoluble CP were determined by Kjeldahl analysis (AOAC, 1995) using the NDF or sequential $\mathrm{ADF}$ residue, respectively. Starch was hydrolyzed with $\alpha$-amylase and amyloglucosidase (3514, Sigma Chemical Co.) as described by Bal et al. (2000), and glucose was measured using a glucose kit (510-A, Sigma Chemical Co.) in a plate reader at $450 \mathrm{~nm}$. Minerals were analyzed using the Applied Research Laboratories (Sunland, CA) model 3560 AES inductively coupled plasma spectrometer system.

Live bacterial numbers of DFM1 and DFM2 were enumerated with species specificity for L. acidophilus and genus specificity for $P$. freudenreichii. Two DFM packages were analyzed for total counts of $L$. acidophilus, and 1 DFM package was analyzed for total counts of Propionibacteria. All samples were analyzed in duplicate. Samples $(1 \mathrm{~g})$ were transferred to tubes containing buffered peptone water and serially diluted to $10^{-6}$, and $0.1-\mathrm{mL}$ aliquots of this dilution were plated onto Man, Rogosa, and Sharpe agar (Becton Dickinson, Sparks, MD) and sodium lactate agar (SLA) plates (Vedamuthu and Reinbold, 1967). Mann-RogosaSharpe plates were incubated at $35^{\circ} \mathrm{C}$ for $24 \mathrm{~h}$, and SLA plates were incubated anaerobically in a sealed jar under an $\mathrm{O}_{2}$-free $\mathrm{CO}_{2}$ atmosphere at $30^{\circ} \mathrm{C}$ for $7 \mathrm{~d}$. After incubation, colonies were counted, and the live bacterial count was calculated using the dilution factors. Colonies in Man, Rogosa, and Sharpe were confirmed with species specificity as $L$. acidophilus using analytical profile index strips (Biomerieux, Marcy
l'Etoile, France) specific for Lactobacillus. Colonies on SLA were identified with genus specificity as Propionibacteria with analytical profile index strips specific for anaerobic organisms.

\section{Digestibility Measurements}

Starting on d 35 of the lactation study, fecal grab samples were collected from cows. Six fecal samples were collected per cow at 5- to 8-h intervals over a 48-h period. Samples were composited by cow. Total mixed ration and feed refusal samples were collected once daily for $5 \mathrm{~d}$ beginning 3 and $2 \mathrm{~d}$, respectively, before the start of the fecal sampling. Analysis of TMR, feed refusals, and fecal samples included DM, NDF, $\mathrm{CP}$, and starch as previously described. Samples were also analyzed for acid insoluble ash (Van Keulen and Young, 1977) to calculate DM, NDF, CP, and starch digestibilities.

\section{Rumen Fermentation Study}

Cows and Diets. A rumen fermentation study was conducted concurrently with the lactation study. Three rumen-cannulated multiparous Holstein cows were randomly assigned to dietary treatments DFM1, DFM2, and control in a $3 \times 3$ Latin square design with 28 -d periods. Periods consisted of $21 \mathrm{~d}$ for adaptation, followed by a 7-d collection period. The compositions of the TMR and of DFM treatments were as previously described for the lactation study. Cows were milked and fed as in the lactation study. At the beginning of the rumen fermentation study, the 3 cows averaged $48 \pm 8$ DIM and $43 \pm 1 \mathrm{~kg} / \mathrm{d}$ of milk.

Sample Collection and Analysis. Rumen fluid was sampled on d 1, 2, 6, and 7 during the last week of each period. Samples were taken just before feeding $(0 \mathrm{~h})$ and 1,3 , and $6 \mathrm{~h}$ after feeding twice daily starting at approximately 0600 and $1400 \mathrm{~h}$, for the morning and evening feedings, respectively. Following collection, rumen samples were strained through 4 layers of cheesecloth and immediately analyzed for $\mathrm{pH}$. Twentyfive milliliters of rumen fluid was acidified with $1 \mathrm{~mL}$ of $50 \%$ sulfuric acid, vortexed, and frozen until analyzed for ammonia using the Kjeldahl procedure (AOAC, 1995). Five milliliters of $25 \%$ metaphosphoric acid was added to $25 \mathrm{~mL}$ of rumen fluid, vortexed, and frozen for VFA and lactic acid analysis. Volatile fatty acids and lactic acid were determined by gas chromatography (Hewlett-Packard 6890, Hewlett-Packard Co., Palo Alto, CA; Erwin et al., 1961) using a $4 \%$ Carbowax 20M/80/120 Carbopack B-DA column (Supelco, Bellefonte, PA). Samples were run at $175^{\circ} \mathrm{C}$ with a flow rate of 24,40 , and $450 \mathrm{~mL} / \mathrm{min}$ for $\mathrm{N}, \mathrm{H}$, and air, respectively. 


\section{Statistical Analysis}

Production data from the lactation study were analyzed as a repeated measures randomized complete block design using the PROC MIXED procedures of SAS (SAS Institute, 1999). Parity was the blocking factor, and cow was included as a random effect. Average milk yield $1 \mathrm{wk}$ before the start of the study was utilized as a covariate, and the first-order autoregressive covariance structure was used. Nonorthogonal contrasts were used to compare DFM1 vs. DFM2 and DFM1 vs. control. The model used was

$\mathrm{Y}_{\mathrm{ijk}}=\mu+\mathrm{C}_{\mathrm{i}}+\mathrm{B}_{\mathrm{j}}+\mathrm{T}_{\mathrm{k}}+\mathrm{W}_{\mathrm{l}}+(\mathrm{BT})_{\mathrm{jk}}+(\mathrm{TW})_{\mathrm{kl}}+\beta+\mathrm{e}_{\mathrm{ijk} \mathrm{l}}$,

where $\mathrm{Y}_{\mathrm{ijk}}=$ observed response; $\mu=$ overall mean; $\mathrm{C}_{\mathrm{i}}=$ random effect of cow; $\mathrm{B}_{\mathrm{j}}=$ effect of block (parity); $\mathrm{T}_{\mathrm{k}}=$ effect of treatment; $\mathrm{W}_{\mathrm{l}}=$ effect of week; $(\mathrm{BT})_{\mathrm{jk}}=$ interaction of block and treatment; $(\mathrm{TW})_{\mathrm{kl}}=$ interaction of treatment and week; $\beta=$ effect of covariate; and $\mathrm{e}_{\mathrm{ijkl}}=$ residual error.

Because PROC MIXED failed to converge for the digestibility data, these data were analyzed as a randomized block design using the PROC GLM procedures of SAS. Cow was assumed to be a fixed effect, and parity was the blocking factor. Nonorthogonal contrasts were used to compare DFM1 vs. DFM2 and DFM1 vs. control. The model used was

$$
\mathrm{Y}_{\mathrm{ij}}=\beta+\mathrm{B}_{\mathrm{i}}+\mathrm{T}_{\mathrm{j}}+\mathrm{e}_{\mathrm{ij}}
$$

where $Y_{i j}=$ value of observation; $\mu$ = general mean; $\mathrm{B}_{\mathrm{i}}=$ effect of block (parity); $\mathrm{T}_{\mathrm{j}}=$ effect of treatment; and $e_{i j}=\operatorname{error}\left(B_{i} \times T_{j}\right)$.

Rumen $\mathrm{pH}, \mathrm{VFA}$, lactic acid, and ammonia data from the rumen fermentation study were analyzed as a Latin square. Data were analyzed using a repeated measures model and the PROC MIXED procedures of SAS. Due to unequally spaced repeated measurements, spatial power law was used as the covariance structure. Nonorthogonal contrasts were used to compare DFM1 vs. DFM2 and DFM1 vs. control. The model used was

$$
\mathrm{Y}_{\mathrm{ijkl}}=\mu+\mathrm{P}_{\mathrm{i}}+\mathrm{C}_{\mathrm{j}}+\mathrm{T}_{\mathrm{k}}+\mathrm{H}_{\mathrm{l}}+(\mathrm{TH})_{\mathrm{kl}}+\mathrm{e}_{\mathrm{ijkl}} \text {, }
$$

where $\mathrm{Y}_{\mathrm{ijkl}}=$ value of observation; $\mu$ = general mean; $\mathrm{P}_{\mathrm{i}}=$ effect of period; $\mathrm{C}_{\mathrm{j}}=$ effect of cow; $\mathrm{T}_{\mathrm{k}}=$ effect of treatment; $\mathrm{H}_{\mathrm{l}}=$ effect of time; and $\mathrm{e}_{\mathrm{ijkl}}=$ residual error.

Milk yield and DMI data taken during the rumen fermentation study were analyzed using the same model, except data were reduced to a period mean and, therefore, time was not included in the model. All treatment results are reported as least square means, and significance was declared at $P<0.05$.

\begin{tabular}{|c|c|}
\hline Item & Amount \\
\hline DM, \% & $\begin{array}{c}42.9 \\
-\% \mathrm{DM}-\end{array}$ \\
\hline $\mathrm{CP}$ & 17.2 \\
\hline NDF & 28.8 \\
\hline Forage NDF & 23.8 \\
\hline $\mathrm{ADF}$ & 15.6 \\
\hline Starch & 24.1 \\
\hline Ether extract & 4.70 \\
\hline $\mathrm{NFC}^{1}$ & 45.0 \\
\hline $\mathrm{OM}$ & 94.1 \\
\hline $\mathrm{Ca}$ & 0.50 \\
\hline Ps & 0.39 \\
\hline $\mathrm{TDN}_{1 \mathrm{X}^{2}}{ }^{2}$ & 76.5 \\
\hline $\mathrm{NE}_{\mathrm{L} 3 \mathrm{X}^{3}}$ (Mcal/kg) & 1.70 \\
\hline
\end{tabular}

Table 2. Nutrient composition of diet

${ }^{1} \mathrm{NFC}=[100-(\mathrm{NDF}-\mathrm{NDICP})+\mathrm{CP}+\mathrm{ash}+\mathrm{EE}]$, where $\mathrm{EE}=$ ether extract and NDICP $=$ neutral detergent insoluble CP.

${ }^{2} \mathrm{TDN}_{1 \mathrm{X}}=$ total digestible nutrients at maintenance DMI as calculated by the 2001 Dairy NRC model (NRC, 2001).

${ }^{3} \mathrm{NE}_{\mathrm{L3X}}=$ net energy for lactation as calculated by the 2001 Dairy NRC model (NRC, 2001).

\section{RESULTS AND DISCUSSION}

The nutrient composition and energy value of the TMR is shown in Table 2. Using a species-specific test for $L$. acidophilus and a genus-specific test for P. freudenreichii, enumeration analysis confirmed the presence of viable $L$. acidophilus and Propionibacteria in DFM1 and DFM2 and the absence of L. acidophilus or Propionibacteria in the control treatment. The $L$. acidophilus concentrations in the DFM1 and DFM2 treatments were $6.20 \times 10^{8}$ and $5.8 \times 10^{8} \mathrm{cfu} / \mathrm{g} \mathrm{com}$ pared with expected values of $2.0 \times 10^{8}$ and $3.0 \times 10^{8}$ cfu/g, respectively. Propionibacterium counts for the DFM1 and DFM2 treatments were $5.0 \times 10^{7}$ and 4.0 $\times 10^{7} \mathrm{cfu} / \mathrm{g}$, respectively, compared with an expected value of $4.0 \times 10^{8} \mathrm{cfu} / \mathrm{g}$. Counts of $L$. acidophilus were very close to expected values, whereas Propionibacterium counts were slightly lower. However, due to complications with the enumeration of Propionibacterium, this analysis was only conducted on 1 sample per treatment. The enumeration analysis results verify the microorganisms being fed were viable and at concentrations approximating target values.

\section{Lactation Study}

Supplementing dairy cows in midlactation with $L$. acidophilus and $P$. freudenreichii did not affect cow performance (Table 3). Feed intake of cows supplemented with $L$. acidophilus and $P$. freudenreichii did not differ from control cows. Milk yield and 4\% FCM were not different between treatments with cows producing $41.6 \mathrm{~kg}$ of milk/d and $36.1 \mathrm{~kg}$ of $4 \% \mathrm{FCM} / \mathrm{d}$ across treatments. Feed efficiency was similar across treat- 
Table 3. Dry matter intake, milk production, and milk composition for the DFM1, DFM2, and control treatments during the 84-d study.

\begin{tabular}{lccccc}
\hline & \multicolumn{4}{c}{ Treatment } \\
\cline { 2 - 4 } Item & DFM1 $^{1}$ & DFM2 $^{2}$ & Control $^{3}$ & SE & $P$-value \\
\hline $\mathrm{N}$ & 17 & 18 & 18 & & \\
DMI, kg/d & 23.9 & 23.6 & 24.2 & 0.73 & 0.71 \\
Milk, kg/d & 42.2 & 41.5 & 41.1 & 1.16 & 0.58 \\
$4 \%$ FCM, kg/d & 36.8 & 35.3 & 36.2 & 1.19 & 0.49 \\
ECM, kg/d & 36.3 & 35.1 & 36.2 & 1.10 & 0.48 \\
FE & 1.54 & 1.52 & 1.51 & 0.05 & 0.74 \\
Fat, kg/d & 1.32 & 1.28 & 1.33 & 0.07 & 0.80 \\
Protein, kg/d & 1.19 & 1.18 & 1.18 & 0.04 & 0.97 \\
Lactose, kg/d & 2.03 & 1.99 & 1.99 & 0.06 & 0.79 \\
Fat, \% & 3.16 & 3.08 & 3.27 & 0.18 & 0.54 \\
Protein, \% & 2.78 & 2.82 & 2.86 & 0.06 & 0.34 \\
Lactose, \% & 4.78 & 4.80 & 4.84 & 0.06 & 0.53 \\
MUN, mg/mL & 18.2 & 18.5 & 18.2 & 0.51 & 0.74 \\
Log 10 SCC/mL & 5.10 & 5.08 & 5.06 & 0.16 & 0.97 \\
\hline
\end{tabular}

${ }^{1} \mathrm{DFM} 1=1 \times 10^{9} \mathrm{cfu} / \mathrm{d}$ of live Lactobacillus acidophilus strain LA747 and $2 \times 10^{9} \mathrm{cfu} / \mathrm{d}$ of live Propionibacterium freudenreichii 1 strain PF24.

${ }^{2} \mathrm{DFM} 2=1 \times 10^{9} \mathrm{cfu} / \mathrm{d}$ of live L. acidophilus strain LA747, $2 \times 10^{9} \mathrm{cfu} / \mathrm{d}$ of live $P$. freudenreichii strain PF24, and $5 \times 10^{8} \mathrm{cfu} / \mathrm{d}$ of L. acidophilus strain LA45.

${ }^{3}$ Control $=5 \mathrm{~g} / \mathrm{d}$ of lactose.

${ }^{4} \mathrm{FE}$ = feed efficiency, $\mathrm{kg}$ of $4 \% \mathrm{FCM} / \mathrm{kg}$ of DMI.

ments, averaging $1.52 \mathrm{~kg}$ of $4 \% \mathrm{FCM} / \mathrm{kg}$ of DMI. Component yields were also similar across treatments, averaging $1.31,1.18$, and $2.0 \mathrm{~kg} / \mathrm{d}$ for milk fat, protein, and lactose, respectively. There was also no treatment effect on the MUN concentration or SCC.

There was no significant effect of treatment on milk fat concentration (Table 3). Across treatments, concentration of milk fat decreased $13.3 \%(P<0.05)$ from wk 1 to 5 (3.49 to $3.02 \%)$. During wk 5 to 10 , milk fat remained constant, averaging $3.01 \%$, and increased $(P$ $<0.05$ ) slightly to $3.19 \%$ at wk 12 . The reason for the decline in milk fat from wk 1 to 5 is unknown. Concentration of milk protein and lactose remained constant throughout the study, with no significant differences $(P>0.10)$ between treatments for milk protein and lactose, averaging 2.82 and $4.81 \%$, respectively.

The effect of $L$. acidophilus plus $P$. freudenreichii supplementation on dairy cow performance was previously investigated by West et al. (2005). Cows were supplemented with $L$. acidophilus $\left(1 \times 10^{9} \mathrm{cfu} / \mathrm{d}\right)$ plus $P$. freudenreichii $\left(2 \times 10^{9} \mathrm{cfu} / \mathrm{d}\right)$ for $70 \mathrm{~d}$, and increases were reported for ECM (36.9 vs. $34.5 \mathrm{~kg} / \mathrm{d})$ and feed efficiency (1.40 vs. $1.30 \mathrm{~kg}$ of ECM/kg of DMI) for cows receiving the DFM compared with the control cows. The difference between our study and that of West et al. (2005) was that a higher-concentrate diet was fed (ratio of 40:60 compared with our 60:40 forage:concentrate). Therefore, cows in the West et al. (2005) study may have had a greater rumen lactic acid concentration and decreased rumen $\mathrm{pH}$ as compared with our study. Nocek et al. (2003) suggested that supple- menting cows with lactate-producing bacteria may decrease total lactic acid concentrations and increase rumen $\mathrm{pH}$ by providing a more constant production or conversion of feed substrates into lactic acid in the rumen than with natural native microbial populations.

\section{Digestibility Study}

Milk yield and DMI of cows fed DFM1, DFM2, or control treatments during the digestibility study (wk 5 of lactation study) were similar (Table 4). Because all cows received the same TMR across treatments and consumed similar amounts of DM, there were no differences in $\mathrm{CP}, \mathrm{NDF}$, or starch intake, averaging $4.02,6.65$, and $5.57 \mathrm{~kg} / \mathrm{d}$, respectively. Apparent total tract digestibilities of DM, NDF, CP, and starch did not differ among treatments (Table 4). Apparent total tract digestibilities of DM, NDF, CP, and starch were within the normal range (Nennich et al., 2003; Oba and Allen, 2003).

The effect of L. acidophilus or P. freudenreichii on $\mathrm{DM}$ or nutrient digestibility of dairy cows has not been previously investigated. Nocek and Kautz (2006) reported increased ruminal digestibility of DM from forage when cows were fed Enterococcus faecium in conjunction with yeast for $21 \mathrm{~d}$ prepartum through 70 DIM. Enterococcus faecium and L. acidophilus are both homofermentative lactic acid bacteria and therefore might be expected to affect rumen fermentation similarly. However, because E. faecium was fed in com- 
Table 4. Milk yield, nutrient intake, and apparent digestibility for DFM1, DFM2, and control treatments during the digestibility period ${ }^{1}$

\begin{tabular}{lccccc}
\hline & \multicolumn{3}{c}{ Treatment } \\
\cline { 2 - 4 } Item & DFM1 $^{2}$ & DFM2 $^{3}$ & Control $^{4}$ & SE & $P$-value \\
\hline $\mathrm{N}$ & 17 & 18 & 18 & & \\
Milk, kg/d & 40.3 & 40.6 & 39.9 & 1.67 & 0.77 \\
DMI, kg/d & 23.1 & 23.1 & 23.3 & 0.69 & 0.98 \\
CP intake, kg/d & 4.01 & 4.01 & 4.03 & 0.12 & 0.98 \\
NDF intake, kg/d & 6.64 & 6.63 & 6.68 & 0.20 & 0.98 \\
Starch intake, kg/d & 5.56 & 5.56 & 5.60 & 0.17 & 0.98 \\
DM digestibility, \% & 66.0 & 65.4 & 65.7 & 0.88 & 0.78 \\
CP digestibility, \% & 70.8 & 70.7 & 70.3 & 0.91 & 0.79 \\
NDF digestibility, \% & 34.7 & 32.7 & 33.9 & 1.71 & 0.61 \\
Starch digestibility, \% & 96.9 & 96.3 & 96.7 & 0.43 & 0.63 \\
\hline
\end{tabular}

${ }^{1}$ Fecal samples collected at d 35 to 36 and feed samples and production data collected at d 32 to 38 .

${ }^{2} \mathrm{DFM} 1=1 \times 10^{9} \mathrm{cfu} / \mathrm{d}$ of live Lactobacillus acidophilus strain LA747 and $2 \times 10^{9} \mathrm{cfu} / \mathrm{d}$ of live Propionibacterium freudenreichii strain PF24.

${ }^{3} \mathrm{DFM} 2=1 \times 10^{9} \mathrm{cfu} / \mathrm{d}$ of live L. acidophilus strain LA747, $2 \times 10^{9} \mathrm{cfu} / \mathrm{d}$ of live Propionibacterium freudenreichi strain PF24, and $5 \times 10^{8} \mathrm{cfu} / \mathrm{d}$ of L. acidophilus strain LA45.

${ }^{4} \mathrm{Control}=5 \mathrm{~g} / \mathrm{d}$ of lactose.

bination with yeast, the digestibility effect cannot be attributed to 1 organism.

\section{Rumen Fermentation Study}

Production parameters, rumen $\mathrm{pH}, \mathrm{VFA}$, and ammonia concentrations for the rumen fermentation study are presented in Table 5. Significant interactions of treatment with hour of sampling were not observed. There was no treatment difference in milk yield or DMI, averaging $41.2 \mathrm{~kg} / \mathrm{d}$ and $25.8 \mathrm{~kg} / \mathrm{d}$, respectively, across treatments. Rumen $\mathrm{pH}$ was also similar $(P>$ $0.10)$ among treatments. Rumen $\mathrm{pH}$ was highest $(P<$ 0.05 ) at $0 \mathrm{~h}$ (just before feeding), averaging 6.42 , and lowest at $3 \mathrm{~h}$ postfeeding, decreasing to 5.98 across treatments.

Other research has reported a decrease in rumen $\mathrm{pH}$ with the feeding of a DFM. Stein et al. (2006) reported rumen $\mathrm{pH}$ was lower in cows fed Propionibacteria at $6 \times 10^{11} \mathrm{cfu} / \mathrm{d}$ compared with cows fed Propionibacteria at $6 \times 10^{10} \mathrm{cfu} / \mathrm{d}$ or control-fed cows (pH 6.65, 6.94, and 6.86 , respectively). This was a greater amount of Propionibacteria fed per day than in our study and may indicate a greater concentration needed to decrease pH. Nocek et al. (2002) reported cows supplemented with a DFM containing $E$. faecium, Lactobacillus plantarum, and Saccharomyces cerevisiae at $10^{5}$ or $10^{7} \mathrm{cfu} / \mathrm{mL}$ of rumen fluid, via a rumen cannula, had a rumen $\mathrm{pH}$ below 5.5 for $13.1 \mathrm{~h}$ as compared with $16.1 \mathrm{~h}$ for cows supplemented at $10^{6} \mathrm{cfu} / \mathrm{mL}$ of rumen fluid. The $10^{5}$ treatment also significantly increased the mean daily $\mathrm{pH}$ to 5.8 , compared with 5.6 and 5.5 for cows supplemented at $10^{6}$ and $10^{7}$, respectively, of the DFM product.
Total VFA concentration did not differ among the DFM1, DFM2, and control treatments and averaged $84.7 \mathrm{mM}$ (Table 5). Average VFA concentration peaked $1 \mathrm{~h}$ postfeeding at $92.0 \mathrm{mM}$ and declined to $81.3 \mathrm{mM}$ at $6 \mathrm{~h}$ postfeeding across treatments. Although L. acidophilus is a homofermentative lactic acid bacteria fermenting carbohydrates solely to lactic acid (Axelsson, 2004 ), in our rumen samples, the concentration of lactic acid was below the detection limit (Table 5). There was no treatment effect on rumen ammonia concentrations (Table 5), with concentrations peaking $1 \mathrm{~h}$ postfeeding (58.8 $\mathrm{mg}$ of $\mathrm{NH}_{3}-\mathrm{N} / \mathrm{L}$ ) and then declining to prefeeding concentrations by $6 \mathrm{~h}$ postfeeding $(52.2 \mathrm{mg}$ of $\mathrm{NH}_{3}-\mathrm{N} / \mathrm{L}$ ). The main end products of Propionibacteria fermentation are propionic acid and acetic acid, along with $\mathrm{CO}_{2}$ and water (Vorobjeva, 1999). However, supplementation with $L$. acidophilus plus $P$. freudenreichii did not result in any difference $(P>0.05)$ in the molar proportions of individual VFA. There was also no difference $(P>0.05)$ in the acetate-to-propionate ratio for the DFM1, DFM2, and control treatments. The lack of differences for lactic acid and VFA concentrations among treatments suggests the DFM treatments may not have resulted in metabolically active $L$. acidophilus or $P$. freudenreichii populations in the rumen.

There is very limited dairy cow research reporting the effect of bacterial DFM supplementation on ruminal VFA, lactic acid, or ammonia concentrations. Kung and Hession (1995) reported that high $\left(8.0 \times 10^{6} \mathrm{cfu} /\right.$ $\mathrm{mL}$ of culture fluid) and low $\left(8.7 \times 10^{5} \mathrm{cfu} / \mathrm{mL}\right.$ of culture fluid) doses of Megasphaera elsdenii in vitro increased total VFA concentrations through $6 \mathrm{~h}$ of fermentation $(126.9$ vs. $63.3 \mathrm{mM})$. At $6 \mathrm{~h}$ of fermentation, there was 
Table 5. Average production parameters, rumen pH, VFA, and ammonia concentrations for the DFM1, DFM2, and control treatments during the rumen fermentation study ${ }^{1}$

\begin{tabular}{lccccc}
\hline & \multicolumn{3}{c}{ Treatment } & & \\
\cline { 2 - 4 } Item & DFM1 $^{2}$ & DFM2 $^{3}$ & Control $^{4}$ & SE & $P$-value \\
\hline $\mathrm{N}$ & 3 & 3 & 3 & & \\
Milk, kg/d & 40.7 & 42.2 & 40.7 & 0.60 & 0.34 \\
$\mathrm{DMI}, \mathrm{kg} / \mathrm{d}$ & 25.9 & 26.0 & 25.6 & 1.15 & 0.96 \\
$\mathrm{pH}$ & 6.20 & 6.15 & 6.15 & 0.03 & 0.80 \\
$\mathrm{Ammonia}, \mathrm{mg} / \mathrm{L}$ & 127.4 & 120.6 & 122.1 & 7.41 & 0.81 \\
Total VFA, mM & 84.6 & 85.1 & 84.3 & 4.20 & 0.99 \\
Lactic acid & $\mathrm{ND}$ & $\mathrm{ND}$ & $\mathrm{ND}$ & & \\
Molar proportion of VFA, mol/100 mol & & & & & \\
Acetate & 65.5 & 63.9 & 64.8 & 0.51 & 0.27 \\
Propionate & 21.7 & 24.1 & 22.4 & 0.36 & 0.07 \\
Butyrate & 9.81 & 9.16 & 9.95 & 0.30 & 0.33 \\
Isobutyrate & 0.72 & 0.69 & 0.68 & 0.03 & 0.61 \\
2-Methylbutyrate & 0.65 & 0.54 & 0.63 & 0.04 & 0.36 \\
Isovalerate & 0.56 & 0.53 & 0.53 & 0.02 & 0.67 \\
Valerate & 1.06 & 1.09 & 1.08 & 0.05 & 0.90 \\
Acetate:propionate & 3.07 & 2.71 & 2.96 & 0.07 & 0.13 \\
\hline
\end{tabular}

${ }^{1}$ Data collected during the last week of each 28 -d period.

${ }^{2} \mathrm{DFM} 1=1 \times 10^{9} \mathrm{cfu} / \mathrm{d}$ of live Lactobacillus acidophilus strain LA747 and $2 \times 10^{9} \mathrm{cfu} / \mathrm{d}$ of live Propionibacterium freudenreichii strain PF24.

${ }^{3}$ DFM2 $=1 \times 10^{9} \mathrm{cfu} / \mathrm{d}$ of live L. acidophilus strain LA747, $2 \times 10^{9} \mathrm{cfu} / \mathrm{d}$ of live $P$. freudenreichii strain PF24, and $5 \times 10^{8} \mathrm{cfu} / \mathrm{d}$ of L. acidophilus strain LA45.

${ }^{4} \mathrm{Control}=5 \mathrm{~g} / \mathrm{d}$ of lactose.

${ }^{5} \mathrm{ND}=$ not detectable.

no difference in acetate concentrations. However $M$. elsdenii significantly increased concentrations of propionate, isobutyrate, butyrate, isovalerate, and valerate. Fungal DFM have been reported to increase total and individual VFA concentrations and decrease rumen ammonia concentrations; however, these responses have been inconsistent (Yoon and Stern, 1995).

\section{CONCLUSIONS}

Supplementing dairy cows in midlactation with DFM products containing $L$. acidophilus and $P$. freudenreichii for $84 \mathrm{~d}$ did not affect DMI or milk production and components. There was also no effect of DFM supplementation on apparent diet digestibility or rumen fermentation. Apparent digestibilities of DM, NDF, CP, and starch were similar across treatments. Finally, there were no differences in ruminal $\mathrm{pH}$, concentrations of total or individual VFA, or ammonia among treatments. In conclusion, under the conditions of this study, supplementing midlactation cows with $L$. acidophilus and $P$. freudenreichii did not affect cow performance, diet digestibility, or rumen fermentation.

\section{ACKNOWLEDGMENTS}

We thank Bill Hanson and the staff at the St. Paul Dairy Barn for their data collection contributions and daily care of the animals. Support from the Nutritional Physiology Corporation and the enumeration of bacteria by Francisco Diez was also greatly appreciated.

\section{REFERENCES}

AOAC. 1995. Official Methods of Analysis. 16th ed. AOAC, Arlington, VA.

Axelsson, L. 2004. Lactic acid bacteria: Classification and physiology. Pages 1-67 in Lactic Acid Bacteria-Microbiological and Functional Aspects. S. Salimen, A. Von Wright, and A. Ouwehand, ed. Marcel Dekker Inc, NewYork, NY.

Bal, M. A., R. D. Shaver, A. G. Jirovec, K. J. Shinners, and J. G. Coors. 2000 . Crop processing and chop length of corn silage: Effects on intake, digestion and milk production by dairy cows. J. Dairy Sci. 83:1264-1273.

Erwin, E. S., G. T. Marco, and E. M. Emery. 1961. Volatile fatty acid analysis of blood and rumen fluid by gas chromatography. J. Dairy Sci. 44:1768-1771.

Hintz, R. W., D. R. Mertens, and K. A. Albrecht. 1996. Effects of sodium sulfite on recovery and composition of detergent fiber and lignin. J. AOAC Int. 79:16-22.

Jouany, J. P. 1994. Manipulation of microbial activity in the rumen. Arch. Anim. Nutr. 46:133-153.

Krause, K. M., and D. K. Combs. 2003. Effects of forage particle size, forage source, and grain fermentability on performance and ruminal $\mathrm{pH}$ in midlactation cows. J. Dairy Sci. 86:1382-1397.

Krehbiel, C. R., S. R. Rust, G. Zang, and S. E. Gilliland. 2003. Bacterial direct-fed microbials in ruminant diets: Performance response and mode of action. J. Anim. Sci. 81(E. Suppl. 2):E120-E132.

Kung, L., Jr., and A. O. Hession. 1995. Preventing in vitro lactate accumulation in ruminal fermentations by inoculation with $\mathrm{Meg}$ asphaera elsdenii. J. Anim. Sci. 73:250-256.

Martin, S. A., and D. J. Nisbet. 1992. Effect of direct-fed microbials on rumen microbial fermentation. J. Dairy Sci. 75:1736-1744.

Nennich, T. D., J. G. Linn, D. G. Johnson, M. I. Endres, and H. G. Jung. 2003. Comparison of feeding corn silages from leafy or 
conventional corn hybrids to lactating dairy cows. J. Dairy Sci. 86:2932-2939.

Newbold, J. C. 1995. Microbial feed additives for ruminants. Pages 259-278 in Biotechnology in Animal Feeds and Animal Feeding. R. J. Wallace and A. Chesson, ed. Weinheim, New York, NY.

Nocek, J. E., and W. P. Kautz. 2006. Direct-fed microbial supplementation on ruminal digestion, health and performance of pre- and postpartum dairy cattle. J. Dairy Sci. 89:260-266.

Nocek, J. E., W. P. Kautz, J. A. Leedle, and J. G. Allman. 2002. Ruminal supplementation of direct-fed microbials on diurnal $\mathrm{pH}$ variation and in situ digestion in dairy cattle. J. Dairy Sci. 85:429-433.

Nocek, J. E., W. P. Kautz, J. A. Leedle, and E. Block. 2003. Directfed microbial supplementation on the performance of dairy cattle during the transition period. J. Dairy Sci. 86:331-335.

NRC. 2001. Nutrient Requirements of Dairy Cattle. 7th rev ed. Natl. Acad. Sci., Washington, DC.

Oba, M., and M. S. Allen. 2003. Effects of corn grain conservation method on ruminal digestion kinetics for lactating dairy cows at two dietary starch concentrations. J. Dairy Sci. 86:184-194.

SAS Institute. 1999. SAS User's Guide: Statistics. Version 8.2. SAS Inst. Inc., Cary, NC.

Stein, D. R., D. T. Allen, E. B. Perry, J. C. Bruner, K. W. Gates, T. G. Rehberger, K. Mertz, D. Jones, and L. J. Spicer. 2006. Effects of feeding Propionibacteria to dairy cows on milk yield, milk components and reproduction. J. Dairy Sci. 89:111-125.

Van Keulen, J., and B. A. Young. 1977. Evaluation of acid-insoluble ash as a natural marker in ruminant digestion studies. J. Anim. Sci. 44:282-287.

Van Soest, P. J., J. B. Robertson, and B. A. Lewis. 1991. Methods for dietary fiber, neutral detergent fiber, and non-starch polysaccharides in relation to animal nutrition. J. Dairy Sci. 74:35833597.

Vedamuthu, E. R., and G. W. Reinbold. 1967. The use of candleoats jar incubation for the enumeration, characterization, and taxonomic study of Propionibacteria. Milchwissenchaft 22:428-431.

Vorobjeva, L. I. 1999. Propionibacteria. Kluwer Acad. Publishers, Boston, MA.

Wagner, D. G., J. Quinonez, and L. J. Bush. 1990. The effect of cornor wheat-based diets and yeast culture on performance, ruminal $\mathrm{pH}$, and volatile fatty acids in dairy calves. Agri-Practice 11:7-12.

West, J. W., J. K. Bernard, G. H. Cross, and D. S. Trammell. 2005. Effect of live bacterial inoculants on performance of lactating dairy cows. J. Dairy Sci. 88(Suppl. 1):59. (Abstr.)

Yoon, I. K., and M. D. Stern. 1995. Influence of direct-fed microbials on ruminal microbial fermentation and performance of ruminants: A review. Asian-australas. J. Anim. Sci. 8:533-555. 